\title{
VIRTUAL ELECTRICAL ENGINEERING IN TECHNICAL EDUCATION
}

\author{
Čestmír SERAFÍN*, Univerzita Palackého v Olomouci, Česká republika
}

Přijato: 15. 5. 2021 / Akceptováno: 31. 8. 2021

Typ článku: Teoretická studie

DOI: 10.5507/jtie.2021.011

\begin{abstract}
The presented paper provides an overview of the possibilities of implementing laboratory teaching in the field of electrical engineering and electronics using an online environment of applications that are freely available to users. The teaching of electrical and electronic subjects are based on the acquisition of basic theoretical and practical knowledge and skills, which pupils or students verify on specific examples and especially in practical laboratory tasks. However, thanks to the ongoing Covid-19 pandemic, these activities have necessitated a relatively fundamental overhaul, not so much in its theoretical basis focused on the practical side, but above all in its form, towards a connectivity approach in the form of tools based on "virtual labs".
\end{abstract}

Key words: Electrical engineering; electronics; education; didactics; connectivism; virtuality; simulation.

\section{VIRTUÁLNÍ ELEKTROTECHNIKA V TECHNICKÉ EDUKACI}

\begin{abstract}
Abstrakt: Předložený přispěvek přináší pohled na možnosti realizace laboratorní výuky v oblasti elektrotechniky a elektroniky za pomocí on-line prostředí aplikací, které jsou uživatelům volně dostupné. Výuka elektrotechnických, potažmo elektronických předmětů je založena na získání základních teoretických i praktických znalostí a dovedností, které si žáci či studenti ověřují na konkrétních příkladech a především v praktických laboratorních úlohách. Tyto aktivity však díky probíhající pandemii Covid-19 doznaly nutnosti poměrné zásadní revize, ne tak ve své teoretické bázi zaměřené na praktickou stránku, ale především ve své formě, $v$ príklonu ke konektivistickému pojetí v podobě nástrojů založených na bázi „virtuálních laboratoří".
\end{abstract}

Klíčová slova: Elektrotechnika; elektronika; edukace; didaktika; konektivismus; virtualita; simulace.

*Autor pro korespondenci: cestmir.serafin@upol.cz 


\section{1 Úvod}

Elektrotechnika, respektive elektronika - to jsou tradiční obory, s jejichž produkty se potkáváme na každém kroku. Kromě toho, že naše domy svítí a je v nich teplo, že je př́ijemné mít televizi, je i skvělé mít díky počítači celý svět na dosah ruky. Nic z toho bychom neměli bez odborníků - elektrotechniků, elektroniků, techniků. Jejich prríprava je otázkou vzdělávání v systému odborného školství, kde výuka elektrotechnických předmětů je zaměřena na získání základních teoretických i praktických znalostí, kde si žáci, studenti vyzkoušejí získané teoretické poznatky na konkrétních praktických příkladech (J. Dostál, 2015).

Výuka elektrotechniky či elektroniky je v mnohém zvláštní od výuky v jiných oborech, a to i těch technických či přírodovědných. Její zvláštnost vyplývá zejména z fyzické neuchopitelnosti zákonitostí a jevů, které tento (tyto) obor (y) provázejí. Didaktiku elektrotechniky můžeme charakterizovat jako teorii a praxi vyučování a učení elektrotechnickým předmětům ve vztahu k výchově a formování znalostí, dovedností, kompetencí, postojů a jiných dispozic, je to souhrn didaktik jednotlivých elektrotechnických předmětů, ale není sumou těchto didaktik. Obdobně bychom mohli charakterizovat didaktiku elektroniky. Charakterizujeme-li didaktiku elektrotechnických (př́padně elektronických) předmětů jako vědu, pak didaktiku elektrotechniky (elektroniky) chápeme jako interdisciplinární, samostatnou hraniční vědní disciplínu, která didakticky zpracovává poznatky elektrotechniky (elektroniky) a integruje je s poznatky společenských věd v didaktickou soustavu elektrotechnických (elektronických) předmětů. Charakteristické pro tuto soustavu je spojení teoreticko-odborné složky se složkou prakticko-odbornou, kdy nelze tyto dvě složky od sebe absolutně separovat, nebot jsou obě nezbytné pro pochopení zákonitostí, jevů a souvislostí z elektrotechniky či elektroniky.

Výše uvedené vymezení z pohledu pedagogického, respektive didaktického hlediska je trvalé a neměnné ve smyslu vymezení, ale proměnné a nestálé ve smyslu forem a metod. Právě tuto proměnnost vnímáme v posledním roce, kdy díky pandemii Covid-19 se poměrně zásadně změnily možnosti a tím i nástroje realizující pedagogický - oborově didaktický přístup k předávání poznatků žákům a studentům na všech stupních a úrovních vzdělávacího systému, a to celosvětově. Ano, můžeme namítnout, že se obecně hodně změnilo od dob, kdy jsme při analýze jevů v elektrických obvodech ještě neměli k dispozici osobní počítače, a tedy trend změn byl dlouhodobý, ovšem je fakt, že k radikální proměně došlo právě díky pandemii a s ní souvisejících omezení. Toto období učitele donutilo k úva- 
hám do jaké míry přehodnotit dosavadní způsoby výuky praktické elektrotechniky či elektroniky, řešení obvodů atd., s ohledem na daný stav a vývoj.

Je jasné a také pochopitelné, že dnešní studenti jsou nejen samozřejmými uživateli počítačů, ale mnohdy i na poměrně vysoké úrovni programátorských znalostí. Záleží však také na učiteli, zda se na jeho hodinách stanou pouhými „uživateli“ elektrotechnického software a aplikací, kdy si sice budou velmi rychle získávat a analyzovat výsledky, avšak nebudou prŕliš rozumět tomu, co dělají, nebo zda začnou užívat tyto nástroje $k$ řešení praktických problémů. Přestože první případ je pro praktické znalosti důležitý, ve druhém prrípadě se jde na základ, ve kterém se neobejdou bez znalostí teorie, jakož i principů analyzačních metod, implementovaných v softwarových simulátorech obvodů (D. Biolek, 1999).

\section{Modelování, analýza, simulace}

Simulační programy dnes otevírají obrovské pole možností pro analýzu a simulaci dějů v složitých elektronických obvodech. Díky výkonnosti soudobých počítačů a výsledkem historického vývoje, který započal v padesátých letech minulého století, jsou dnes programy určené pro simulaci analogových a digitálních obvodů standardem virtuálních laboratorních nástrojů. Standardem analogové simulace je program SPICE, zatímco u digitální simulace existuje několik softwarových nástrojů, přičemž simulátory s prŕívlastkem „Mixed-Mode“ mají schopnost simulovat obvody na analogové i logické úrovni.

Analýzu elektrických obvodů je možno charakterizovat jako konkrétní postup od modelu obvodu až po získání výsledku. V současné době existující metody analýzy lze rozdělit na nealgoritmické, neboli heuristické a algoritmické (Biolek, 1994). Mezi ty první lze zařadit postupy, které řešitel volí na základě svých i předchozích zkušeností, jedná se tedy o konstruktivistický př́istup. Algoritmická metoda naproti tomu definuje přesný postup - algoritmus, tedy např́klad řešení obvodu metodou uzlových napětí. Každá z těchto metod v řešení plní svou funkci: nealgoritmická nutí řešitele $\mathrm{k}$ tvưrčímu technickému myšlení, algoritmická pak poskytuje nástroj k řešení.

Modelování můžeme definovat jako proces popisování reality omezenými prostředky, kde výsledkem je model originálního objektu. Analýza je pak jednorázová činnost, kdy zkoumáním modelu se pokoušíme zjistit určitou vlastnost originálu a v neposlední řadě simulace je činnost, kdy analýzou modelu se pokoušíme o získání co nejvěrnějšího obrazu chování originálu za přesně definovaných 
podmínek. Při řešení pomocí počítačového programu tak sestavujeme model obvodu pomocí schématického editoru, kdy počítač při tomto sestavování účinně napomáhá tím, že je zdrojem složitých interních modelů součástek (tranzistory, operační zesilovače, integrované obvody...). Vlastní sestavení rovnic, jejich řešení a vizualizace výsledků je pak již plně v režii programu.

Programy pro řešení obvodů se někdy dělí na analyzační (analyzátory) a simulační (simulátory). Rozdíl mezi nimi však není většinou nijak ostrý, nebot jsou ve větší či menší míře schopny v obou kategoriích realizovat škálu různých typů analýz s využíváním i složitých modelů zakomponovaných do knihoven prvků.

Analýza modelu má své cíle, vstupy a výstupy, metodu, formu i prostředky realizace. Forma analýzy je pak dána především prostředkem její realizace, tedy počítačem s př́slušným softwarem, přičemž forma interních analyzačních procedur je uživateli skryta a závisí na použitých numerických algoritmech a jejich naprogramování ze strany tvůrců softwaru. Kromě výpočetních cílů může mít analýza i cíle jiné, kdy například vyučující může přiřadit cíle pedagogické (procvičení konkrétní metody analýzy, pochopení určitého děje v obvodu, apod.). K základním pedagogickým cílům při výuce analýzy patří (D. Biolek, 1994):

1. Podporovat tvưrčí způsob myšlení žáků a studentů s využitím základních zákonů (Ohmův zákon, Kirchhoffovy zákony) a principů (princip superpozice, ekvivalence,...). Analýza by měla přispívat k lepšímu chápání funkce obvodu. Žák či student v tomto prrípadě vlastně cvičí svůj „elektrikářský cit“ na to, zda rozložení napětí a proudů je reálné či nikoliv, a jak z dosud získaných dílčích výsledků získat další.

2. Zvládnout účinný nástroj - algoritmickou metodu analýzy $\mathrm{k}$ „ručnímu“ řešení obvodů.

3. Porozumět principům metod analýzy obvodů, implementovaných v běžně používaných simulačních programech.

Fenomén simulačních programů pro elektrotechniku resp. elektroniku nerozlišuje hranice mezi stupni škol. Závisí zde však na využívání těchto programů na školách, které může být i kontraproduktivní (D. Biolek 1, 1999).

Počítačová simulace a analýza obvodů se dnes realizuje především v těchto oblastech (D. Biolek 2, 1999):

1. Využití speciálního softwaru - typickými představiteli jsou programy jako TINA, MicroCap, Multisim, apod.).

2. Využití univerzálních programů pro matematicko-vědecké výpočty jako napríklad MATLAB, MAPLE, apod. 
Na první pohled by se mohlo zdát, že pro práci se simulačním programem SPICE uživatel nepotřebuje o zabudovaných algoritmech vlastně př́liš vědět, uživatel však často nad programem ztrácí i nevědomky kontrolu, protože není jeho tvůrcem a nerozumí základním procesům jeho fungování. Uživatel tak často akceptuje simulační výstupy i tehdy, jsou-li výsledky v rozporu s realitou např́íklad díky ne vhodně nastaveným podmínkám simulace.

\section{Problémy simulačních programů z pohledu studentů/uživatelů}

Simulace elektrického obvodu se může více či méně odlišovat od reálného obvodu - základem je pro toto zahrnutí či nezahrnutí všech podmínek a okolností do modelu, které mají na měření vliv. Nejedná se tedy jen o sestavení modelu obvodu, ale také zahrnutí dalších podmínek - nastavení parametrů simulace, které by ovšem př́slušný program případně měl nabízet. Na druhou stranu, pokud uživatel ponechá implicitní nastavení, pak musí počítat s tím, že v některých situacích může být výsledek simulace jiný, než by byl v reálném obvodu. Pro nastavení parametrů je pak potřeba:

a) Program toto nastavení umožňoval, př́ípadně nabízel uživateli možnost ovlivnit některé parametry modelu obvodu, případně modelů měřicích přístrojů.

b) Programy většinou sestavují rovnice obvodu na základě metody uzlových napětí. Neznámými veličinami, jsou tedy napětí mezi jednotlivými uzly a tzv. referenčním uzlem (označen značkou uzemnění). Znamená to, že program vždy řeší celou soustavu rovnic a tedy všechny neznámé.

c) Odezva modelu obvodu na daný budicí signál závisí nejen na tomto signálu, ale i na tzv. počátečních podmínkách, $\mathrm{v}$ nichž se obvod nacházel $\mathrm{v}$ okamžiku připojení budicího signálu. Př́kladem může být průběh nabíjení kondenzátoru, který připojíme ke zdroji o určitém vnitřním odporu. Tento průběh závisí na stavu, na jakém napětí byl kondenzátor nabit v okamžiku připojení. Program rozumí pod pojmem počáteční podmínky množinu všech neznámých v počátečním okamžiku simulace, tedy implicitně je nastaví na nulu. Tady je potřeba zdůraznit, že implicitní nastavení nelze použít, pokud zkoumáme jeho vybíjení.

Metody analýzy elektrických obvodů by měly plnit nejen funkci nástroje pro řešení, ale učitel jich může využívat i k výkladovým účelům. Je ovšem nutné ke správnému používání počítačových programů pro simulaci obvodů ze strany uživatele alespoň minimální teoretická průprava, spočívající v porozumění pojmů 
jako jsou počáteční podmínky, nelineární a lineární obvod, přechodný děj, ustálený stav, apod. Př́stup k výuce v tomto pojetí má tedy mnohem odlišné znaky od klasické laboratorní výuky a kombinuje různé metody a postupy. $\mathrm{CH}$. Levert a S Pierre (2000) nabízejí metodiku - všeobecně pojímanou koncepci o modelování virtuální laboratoře a využití simulačních modelů které by měly fungovat v různých konfiguracích a na různých platformách (Y. K. Michael, 2001; V. Musil a P. Dobrovolný, 1997).

\section{On-line aplikace z pohledu studentů učitelství technických předmětů}

Simulátor elektrického obvodu je postaven na snaze předpovědět chování skutečného, reálného obvodu. Pasivní i aktivní součástky, měřicí přístroje jsou ve schematickém zapojení nahrazeny modely s vlastnostmi, které více či méně reprezentují skutečné součástky a přistroje a které více či méně nabízení úpravu svých parametrů pro potřeby zajištění reálnosti modelu.

V předchozích kapitolách bylo uvedeno, že počítačová simulace a analýza elektrických obvodů se může realizovat využití speciálního softwaru - tuto oblast, však můžeme ještě dále rozdělit na dvě kategorie:

1. specializovaný software v podobě počítačového programu, který si uživatel instaluje do počítače, tabletu či mobilu a který může být freewarem, sharewarem (časovým - trialwarem, funkční - cripplewarem, omezujícím komfort - adwarem, nagwarem), demoverzí nebo licencovaným produktem za poplatek;

2. on-line aplikace umožňující uživateli vytvářet simulace on-line na internetu bez potřeby stahovat produkt do počítače. I tady se lze setkat s různými licenčními podmínkami vyžadujícími bud jen registraci a zřízení uživatelského účtu, nebo poplatek za registraci (jednorázový či pravidelný). 


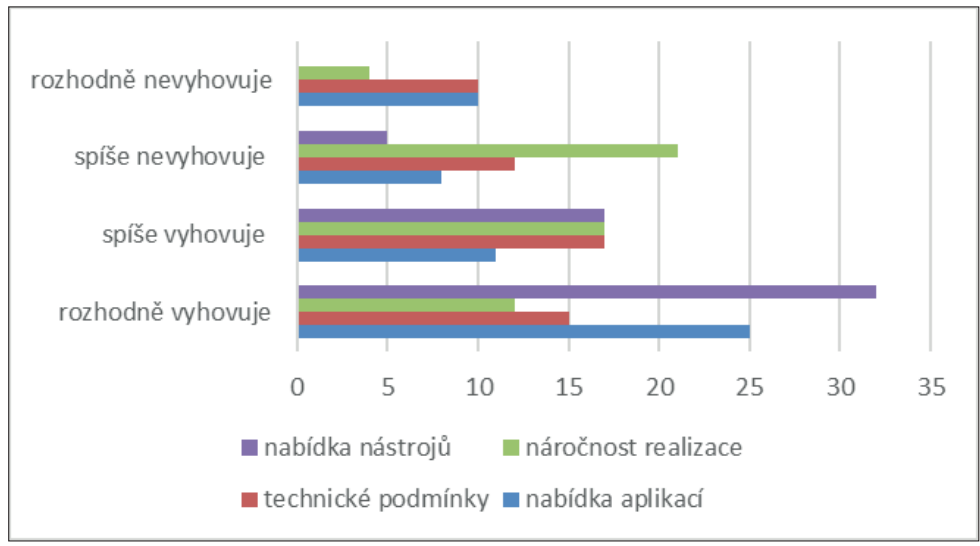

Obr. č. 1: Pohled studentů na užití aplikací

V rámci průzkum, který byl realizován $\mathrm{v}$ roce 2020 a na počátku roku 2021 byli osloveni studenti učitelství technických předmětů $\mathrm{v}$ bakalářském stupni $\mathrm{v}$ průběhu výuky praktických předmětů zaměřených na laboratorní výuku elektrotechniky a elektroniky a získávány jejich pohledy na virtuální on-line laboratoře - simulátory elektrických obvodů. Cílem průzkumu bylo získat informace o postojích studentů k on-line aplikacím, jejich relevantnosti z pohledu edukace a realizovatelnosti příslušných měřicích úloh z oblasti elektrotechniky a elektroniky. Průzkumu se zúčastnilo 54 studentů v prezenční $\mathrm{i}$ kombinované formě studia.

Otázky směřovaly na to, zda nabídka nástrojů aplikací je pro realizaci daných úloh vyhovující, zda náročnost realizace obvodové simulace je velká či malá, zda technické podmínky, tj. náročnost na počítač, připojení k internetu, případně cenová politika ale i třeba jazyk aplikace jsou pro ně jako uživatele vyhovující a v neposlední řadě směřoval dotaz na nabídku aplikací na internetu, zda bylo možno vybírat či výběr byl omezený. Odpovědi jsou shrnuty a prezentovány na obr. $1 . Z$ uvedeného grafu je patrné, že nabídka nástrojů i vlastních aplikací je pro daný účel pro studenty vyhovující a naplňuje podmínky realizace úloh, které měli vytvářet - simulovat $\mathrm{z}$ oblasti elektrotechnik a elektroniky. Už tak nejednoznačné je to u náročnosti realizace a technických podmínek. Zde se respondenti vyjadřovali váhavěji - mezi „spíše vyhovuje“ až „spíše nevyhovuje“. Z odpovědí vyplývalo, že respondenti měli problém jak na jazykové úrovni (aplikace jsou většinou v anglickém jazyce), tak v otázkách licencování (nutnost zaregistrovat se, 
prrípadně zaplatiti poplatek za registraci). Rovněž se potýkali s tvorbou vlastního obvodu a nastavení parametrů v př́slušné simulaci včetně vyhledání vhodných nástrojů, měřících přístrojů.

V neposlední řadě respondenti pochopitelně také uváděli, které simulační aplikace využívali. Tyto odpovědi jsou shrnuty na obr. 2, přičemž na ose x je počet studentů využívajících danou aplikaci. Jedná se celkem o 6 aplikací, z nichž 4 byly on-line. Program Edison (obr. 3) od firmy DesignSoft pracující na platformě programu TINA byl v demoverzi respondenty stahován a instalován do počítače. Program TINA sice také umožňuje práci v cloudu ${ }^{1}$ ale za roční platbu. Program Edison (resp. Tina) je kvalitní simulační nástroj, který spojuje modelování schéma elektrického obvodu s 3D vizualizací jednotlivých komponent na pracovní desce. Program nabízí i experimenty s problémovými úlohami a je distribuován i v českém jazyce. Další vývoj tohoto nástroje však již od verze 5 nepokračuje.

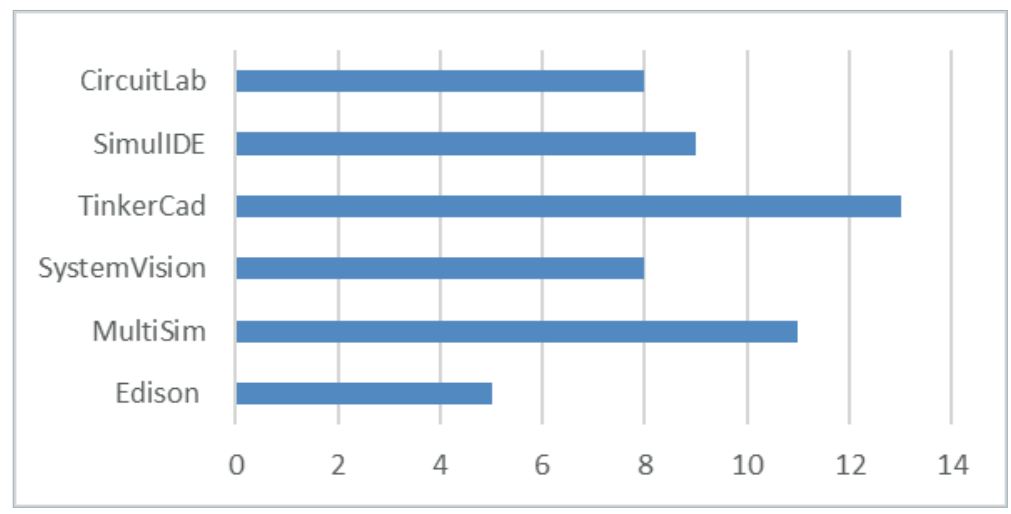

Obr. č. 2: Aplikace, které studenti/respondenti používali pro vytváření simulací

Dalším programem, který vyžadoval instalaci je SimulIDE² (obr. 4), což je jednoduchý simulátor elektrických obvodů včetně mikrokontrolérů podporující PIC i Arduino. Není to dobrý nástroj pro analýzu obvodů, ale je jednoduchý a snadno použitelný.

\footnotetext{
${ }^{1}$ https://www.tina.com/tinacloud

${ }^{2}$ https://www.simulide.com/p/home.html
} 


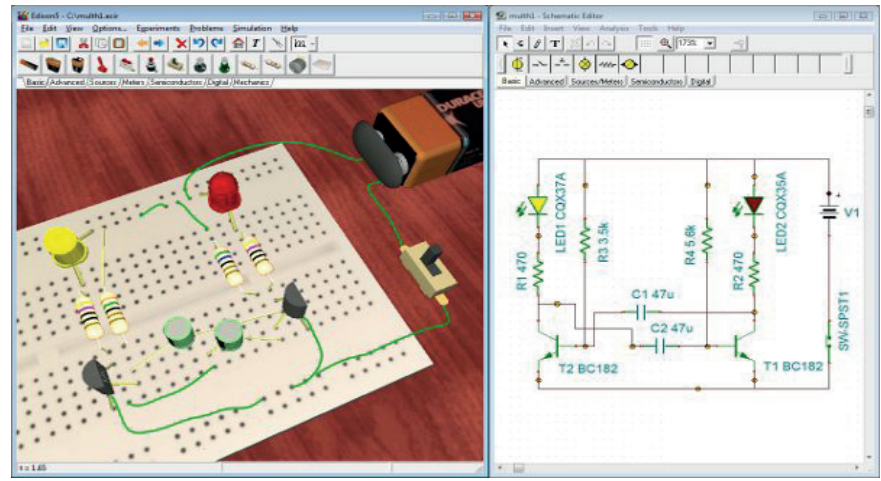

Obr. č. 3: Program Edison

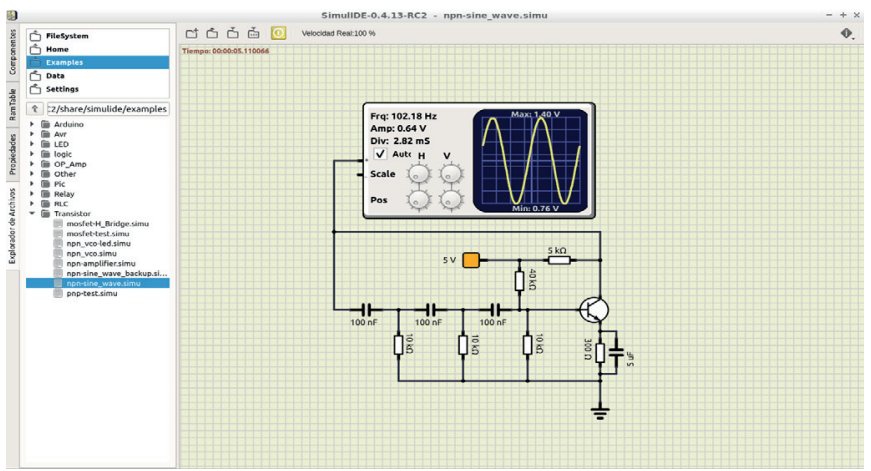

Obr. č. 4: Program SimullDE

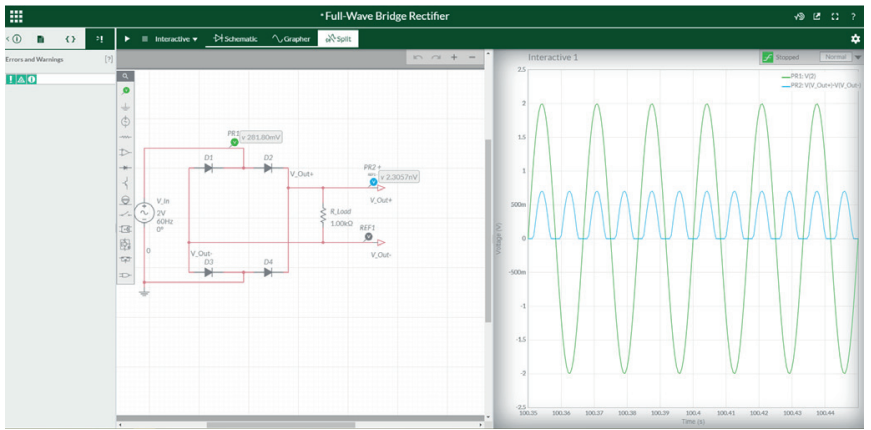

Obr. č. 5: Aplikace Multisim Live 
Mezi online simulační nástroje pak byly respondenty používány Multisim Live $^{3}$ (obr. 5), který umožnuje užívat stejnou simulační technologii jako program Multisim od firmy National Instruments. Program poskytuje prostředí založené na standardu SPICE. Zahrnuje analogovou, digitální a výkonovou elektroniku. Program navíc umožňuje simulované obvody srovnat se skutečnými obvody tedy $s$ reálným měřením $v$ prostředí Measurements Live pomocí osciloskopu NI ELVIS III. Aplikace má př́stup zdarma (po zaregistrování) ale v omezeném rozsahu, plný přistup (zahrnující např́ílad úpravu parametrů modelu) je za poplatek.
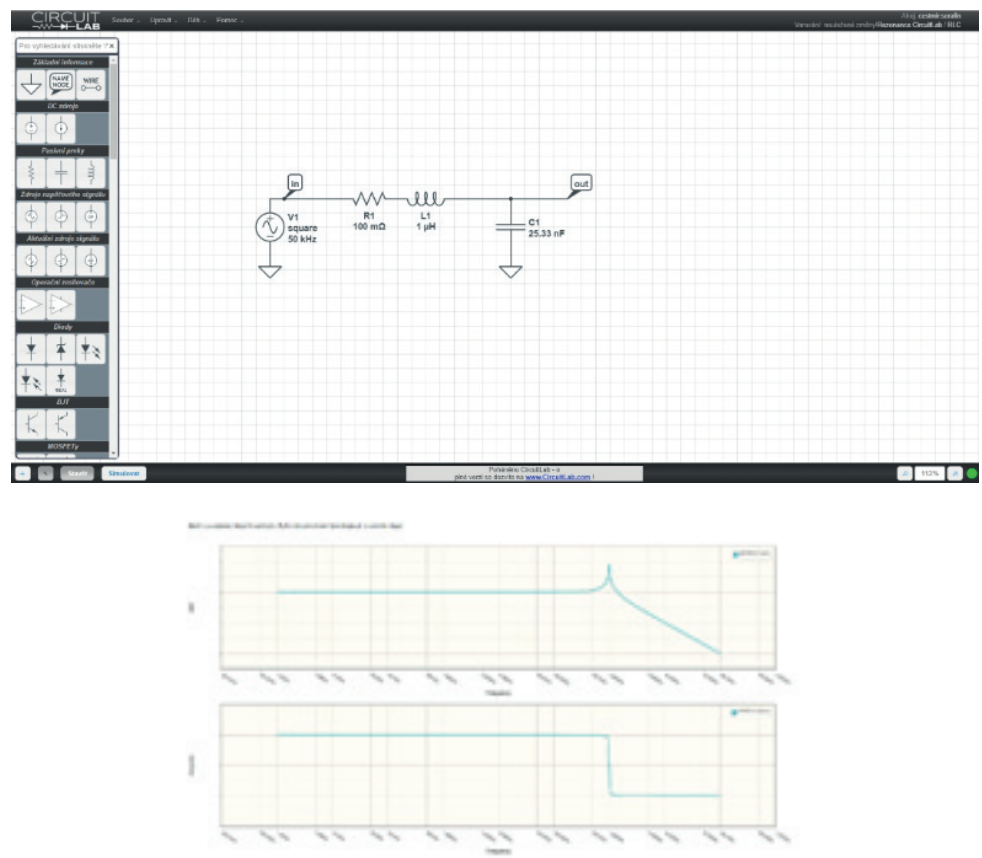

Obr. č. 6: Aplikace CircuitLab

Další aplikací je CircuitLab ${ }^{4}$ (obr. 6) - aplikace vyžaduje registraci a má omezené využití na maximálně 10 položek na schéma. Použíání je zpoplatněno pro komerční

\footnotetext{
${ }^{3}$ https://www.multisim.com/

${ }^{4}$ https://www.circuitlab.com/
} 
a studentské užití. K dispozici jsou videonávody a interaktivní učebnice elektroniky (v angličtině).

Mezi on-line simulátory patří také SystemVision Cloud ${ }^{5}$ (obr. 7) (fy Siemens), která je zdarma, př́padně po zaregistrování a pro náročnější požadavky je nutné předplatné. Aplikace je určena pro simulace analogových, digitálních, smíšených obvodů i mechatronických systémů. Schematické symboly (bloky) potřebné pro kreslení diagramu jsou rozděleny do skupin: Analog a Digital Electronics, Magnetic and Electromechanical, Thermal and Electrothermal, Three Phase Power, Continuous Function Blocks.

Systém aplikací Tinkercad ${ }^{6}$ (obr. 8) je rovněž bezplatný online nástroj pro 3D modelování. Jedná se o platformou pro vytváření modelů pro 3D tisk pro konstruování geometrie těles. Aplikace používá ke konstrukci modelů zjednodušenou metodu konstruktivní objemové geometrie (T. Dahl, 2012). Kromě standardní knihovny může uživatel vytvářet vlastní generátory tvarů pomocí vestavěného editoru JavaScriptu. Tinkercad také obsahuje funkci pro export 3D modelů pro 3D tisk a do Minecraft Java Edition (B. Heater, 2013) a také nabízí možnost navrhovat struktury pomocí Lego kostek.

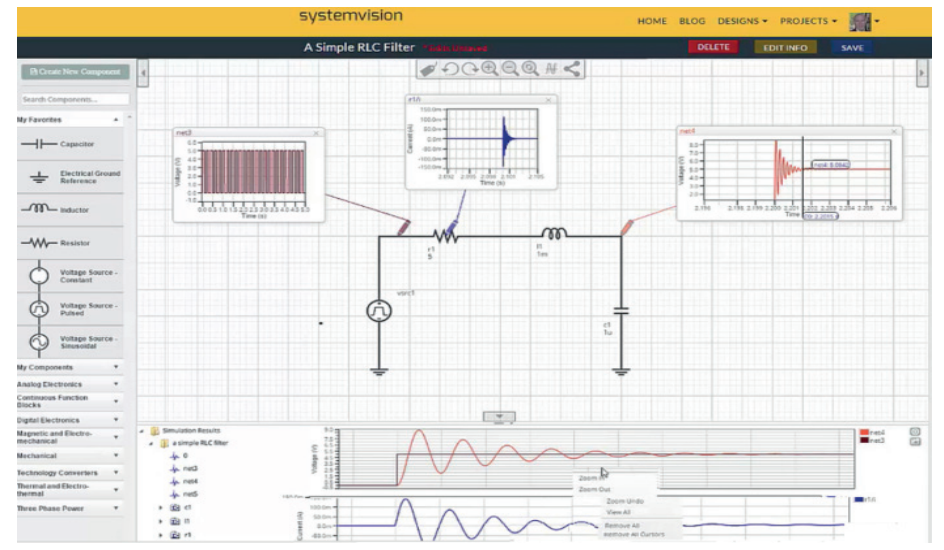

Obr. č. 7: Aplikace SystemVision Cloud

\footnotetext{
${ }^{5}$ https://www.systemvision.com/

${ }^{6}$ https://www.tinkercad.com/
} 


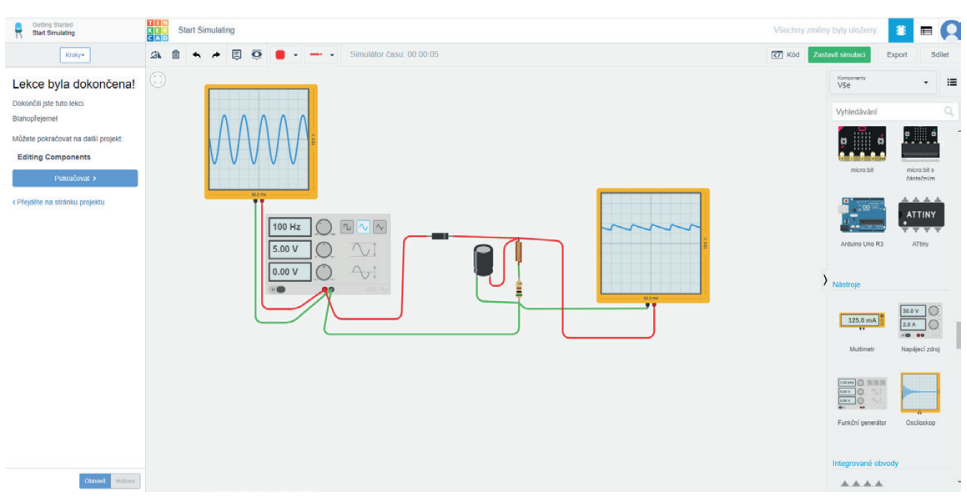

Obr. 8: Aplikace Tinkercad pro elektrotechniku a elektroniku

\section{Závěr}

Simulační programy jsou nedocenitelnou pomůckou v analýze elektrických resp. elektronických obvodů, díky tomu, že přinášejí mnohé možnosti v jejich testování, a to jak amatérsky simulací obvodů před jejich fyzickou realizací, tak edukačně didakticky nácvikem správné realizace obvodů, př́ípadně řešením problémových úloh, či přístupem badatelskou formou. Základem je ovšem dostatečná digitální gramotnost $\mathrm{v}$ práci s nimi, a to nejen po stránce vlastní simulace, ale také po stránce pochopení jevů a souvislostí, které simulujeme. Tato okolnost se částečně promítla i do předloženého výzkumného šetření, nebot volba nástrojů, se kterými respondenti pracovali v rámci předložených měřících úloh byla na nich. Studentům byly různé nástroje doporučovány a rovněž byli vyzýváni k jejich vyhledávání na internetu. Průzkum je tak položen na stanovisku/názorech respondentů, kteř́ si volili př́slušný on-line nástroj podle svých schopností, znalostí i dovedností a takto je také hodnotili. Mezi nejpoužívanější nástroje se tak zařadili aplikace Tinkercad a Multisim Live.

Hlavní výhodou simulačních programů, online aplikací je, že díky nim se lze vyhnout případům, které $\mathrm{v}$ reálném prostředí mohou vést $\mathrm{k}$ nemalým materiálovým ztrátám formou zničených součástek nebo i vlastních měřících přístrojů. Mezi další výhody, lze pak zařadit jejich dostupnost odkudkoli při minimu materiálových i technologických nákladů a mnohdy také jednoduchost a intuitivnost v ovládání i tvorbě elektrických obvodů. Naproti tomu hlavní nevýhodou je 
vlastní model, jeho kvalita v zahrnutí vlivů a okolností, které mnohdy v reálném obvodu bereme jako samozřejmost, ale v simulovaném je musíme, pokud to lze, do obvodu dodat, aby byly výsledky srovnatelné s těmi reálnými.

\section{Literatura}

Biolek, D. (1994). Výuka obecných metod analýzy lineárních obvodů. STO-5, VA Brno, s. 1-4. Dostupné na http://www.vabo.cz/Stranky/biolek/veda/articles/STO5_2.pdf

Biolek,D. (1) (1999). Respektování didaktických principů při využívání počítačových programů ve výuce elektrických obvodů. ELEKTROREVUE. Dostupné na: http://www.elektrorevue.cz/ clanky/99008/index.htm

Biolek,D, (2) (1999). Využití programů pro symbolickou a semisymbolickou analýzu elektrických obvodů ve výuce i výzkumu. ELEKTROREVUE. Dostupné na: http://www.elektrorevue.cz/ clanky/99012/index.htm

Dahl, T. (2012). 3-D Design for Idiots: An Interview With Tinkercad Founder Kai Backman Wired. com. Dostupné na: https://www.wired.com/2012/06/interview-with-tinkercad-founder-kaibackman/

Dostál, J. (2015) Badatelsky orientovaná výuka: kompetence učitelů k její realizaci v technických a prírodovědných předmětech na základních školách. Olomouc: Univerzita Palackého v Olomouci. ISBN 978-80-244-4515-1

Heater, B. (2013). Tinkercad lets you export 3D designs into Minecraft. Engadget. Dostupné na: https://www.engadget.com/2013-08-14-tinkercad-minecraft.html?guce_referrer=aHR0cHM6 Ly9lbi53aWtpcGVkaWEub3JnLw\&guce_referrer_sig=AQAAAHFbs8ymfoGdX9zOypZwynS QWYjMOAtQ2OcFhxaBhjn6SrruMUHSjCAlbvHbIwa9NUPPGQ9EmHZWQ9PYwatzhv W2 w2rG6LiZPDgTDpAhQReWOrbt_pFy8bFn4R6gNNqH0 RiaqAkOq UX9oimwAnrR 4arIDiJcq401jjRClhz_m4Tq

Levert, Ch. \& Pierre, S. (2000) Towards a Design Methodology for Distributed Virtual Laboratories. In Bourdeau, J. \& Heller, R. (Eds.) Proceedings of World Conference on Educational Multimedia, Hypermedia and Telecommunications 2000 (pp. 592-597). Chesapeake, VA: AACE.Retrieved

Michael Y. K. (2001) The Effect of a Computer Simulation Activity versus a Hands-on Activity on Product Creativity in Technology Education. Journal of Technology Education. Vol. 13, n. 1. ISSN 1045-1064

Musil, V., Dobrovolný, P. a Stř́ibrný, V- (1997). Modelování a simulace: program PSpice. Brno: PCDIR. Učební texty vysokých škol. ISBN 80-214-0859-6 